\title{
RISIKO RANTAI PASOK PAPRIKA PADA ANGGOTA KELOMPOK TANI DEWA FAMILY, KABUPATEN BANDUNG BARAT
}

\author{
THE SUPPLY CHAIN RISK OF MEMBERS OF \\ DEWA FAMILY FARMERS' GROUP, WEST BANDUNG DISTRICT
}

\author{
Mila Cahya*, Eliana Wulandari \\ Program Studi Agribisnis, Fakultas Pertanian, Universitas Padjadjaran \\ Jl. Raya Bandung - Sumedang, Jawa Barat 45363 \\ *E-mail corresponding: milacahya50@yahoo.com
}

(Diterima 01-07-2019; Disetujui 22-07-2019)

\begin{abstract}
ABSTRAK
Paprika merupakan salah satu komoditas unggulan Jawa Barat yang secara ekonomi dapat diandalkan dalam menunjang kesejahteraan masyarakat dan pembangunan daerah. Kelompok Tani Dewa Family adalah salah satu pelaku rantai pasok paprika yang menampung hasil paprika milik petani di Desa Pasirlangu, Kecamatan Cisarua, Kabupaten Bandung Barat. Berbagai risiko dalam aliran rantai pasok pada anggota Kelompok Tani Dewa Family dapat mengancam keberlangsungan usaha kelompok jika tidak segera diberi penanganan aksi mitigasi. Tujuan penelitian ini adalah mengidentifikasi aliran pada rantai pasok paprika, dan menganalisis risiko-risiko yang terjadi pada rantai pasok paprika pada anggota Kelompok Tani Dewa Family, serta menentukan aksi mitigasi yang dapat meminimalisasi risiko-risiko yang muncul tersebut. Penelitian ini menggunakan analisis deskriptif dan House of Risk. Hasil penelitian menunjukkan bahwa terdapat 24 peristiwa risiko yang terkait dengan aktivitas rantai pasok yang dihadapi anggota Kelompok Tani Dewa Family. Untuk meminimalisir munculnya agen risiko prioritas, terdapat 9 aksi mitigasi pada anggota Kelompok Tani Dewa Family.
\end{abstract}

Kata kunci: Paprika, Kelompok Tani, House of Risk, Risiko Rantai Pasok

\section{ABSTRACT}

Paprika is one of the leading commodities in West Java, which is economically reliable in supporting community welfare and regional development. Dewa Family Farmers' Group is one of the paprika producers who collects paprika from farmers in Pasirlangu Village, Cisarua SubDistrict, West Bandung District. Various risks in the supply chain flow faced by the members of the Dewa Family Farmers' Group can threaten the sustainability of the farmers' group business. The purpose of this study is to identify the flow of the paprika supply chain, and to analyze the risks that occur in the paprika supply chain of members of the Dewa Family Farmers' Group, and to determine mitigation actions that can minimize the risks. This study used descriptive and House of Risk analysis. The results showed that there were 24 risk events related to supply chain activities faced by members of the Dewa Family Farmers' Group. To minimize the appearance of priority risk agents, there are 9 mitigation actions for members of the group.

Keywords: Paprika, Farmers' Group, House of Risk, Supply Chain Risk 
RISIKO RANTAI PASOK PAPRIKA PADA ANGGOTA

\section{KELOMPOK TANI DEWA FAMILY, KABUPATEN BANDUNG BARAT}

Mila Cahaya, Eliana Wulandari

\section{PENDAHULUAN}

Pertanian merupakan sektor yang fundamental dalam suatu negara agraris, contohnya Indonesia. Sektor pertanian adalah sumber mata pencaharian sebagian besar masyarakat Indonesia. Data Badan Pusat Statistik (BPS) tahun 2018 menunjukkan 88,27\% penduduk Indonesia memiliki lapangan pekerjaan utama di sektor pertanian. Sub sektor hortikultura merupakan salah satu sub sektor pertanian yang berpotensi untuk dikembangkan karena memiliki nilai ekonomis yang cukup tinggi. Sub sektor hortikultura meliputi sayuran, buahbuahan, tanaman hias, dan tanaman biofarmaka atau obat-obatan.

Paprika termasuk ke dalam tanaman hortikultura dari golongan sayuran yang umumnya dimanfaatkan untuk keperluan pangan. Selain bermanfaat untuk kebutuhan konsumsi rumah tangga, juga bermanfaat dalam industri pengolahan makanan. Paprika merupakan komoditas sayuran asing yang potensial untuk dikembangkan di Indonesia serta bernilai ekonomis tinggi (Savaringga, 2013). Hal tersebut ditunjukkan dengan tingginya permintaan terhadap paprika, seperti permintaan dari hotel berbintang, restoran-restoran mewah, meningkatnya turis asing yang datang dan tinggal di Indonesia, dan semakin populernya makanan barat di Indonesia. Pada tahun 2014 produksi paprika menunjukkan peningkatan menjadi 7.031 ton (Ditjenhorti, 2015). Peluang pasar luar dan dalam negeri terbuka lebar karena pasokannya lebih kecil dibandingkan permintaannya. Widaningrum dkk (2016) menyatakan produksi paprika dalam negeri belum mampu memenuhi permintaan dalam negeri sedangkan pasar ekspor paprika Indonesia telah mencapai Taiwan, Singapura dan beberapa negara lainya. Malaysia dan Singapura meminta 10 ton paprika per minggu, akan tetapi permintaan tersebut baru dapat terpenuhi sekitar 4-6 ton saja oleh petani paprika di Pasirlangu, Jawa Barat.

Penyumbang terbesar produksi paprika nasional yaitu daerah Jawa Barat karena merupakan daerah yang cocok untuk ditanami tanaman hortikultura khususnya sayuran seperti paprika, dimana produksi paprika di Jawa Barat sebesar 5.104 ton pada tahun 2017 dapat dilihat pada Tabel 1. 
$\underline{\text { Tabel 1. Perkembangan Produksi Paprika di Indonesia Pada Tahun 2014-2017 }}$

\begin{tabular}{|c|c|c|c|c|c|}
\hline \multirow{2}{*}{ Propinsi } & \multicolumn{4}{|c|}{ Produksi Paprika (Ton) } & \multirow{2}{*}{$\begin{array}{c}\text { Rata-rata } \\
\text { Produksi 2014 } \\
2017 \text { (Ton) }\end{array}$} \\
\hline & 2014 & 2015 & 2016 & 2017 & \\
\hline Aceh & 0 & 0 & 7 & 0 & 1,75 \\
\hline Sumatera Utara & 0 & 6 & 0 & 0 & 1,5 \\
\hline Riau & 0 & 0 & 0 & 3 & 0,75 \\
\hline Jambi & 0 & 1 & 0 & 0 & 0,25 \\
\hline Sumatera Selatan & 2 & 0 & 0 & 0 & 0,5 \\
\hline Jawa Barat & 4.489 & 3.333 & 3.127 & 5.104 & $4.013,25$ \\
\hline Jawa Tengah & 12 & 110 & 0 & 4 & 31,5 \\
\hline Jawa Timur & 2.065 & 1.916 & 1.925 & 2.038 & 1.986 \\
\hline Banten & 0 & 0 & 0 & 3 & 0,75 \\
\hline Bali & 361 & 282 & 114 & 216 & 243,25 \\
\hline Nusa Tenggara Barat & 11 & 7 & 45 & 9 & 18 \\
\hline Nusa Tenggara Timur & 0 & 1 & 1 & 3 & 1,25 \\
\hline Sulawesi Tengah & 0 & 2 & 30 & 0 & 8 \\
\hline Sulawesi Selatan & 73 & 0 & 0 & 0 & 18,25 \\
\hline Sulawesi Tenggara & 0 & 0 & 1 & 0 & 0,25 \\
\hline Sulawesi Barat & 10 & 0 & 0 & 0 & 2,5 \\
\hline Maluku & 5 & 0 & 5 & 0 & 2,5 \\
\hline Papua & 0 & 0 & 1 & 9 & 2,5 \\
\hline
\end{tabular}

Sumber: BPS 2015-2018

Salah satu kabupaten di Provinsi Jawa Barat yang menjadi sentra produksi paprika adalah Kabupaten Bandung Barat. Kabupaten Bandung Barat mempunyai lokasi yang strategis sebagai wilayah pengembangan komoditas hortikultura, khususnya komoditas paprika. Dalam laporan BPS dan Departemen Pertanian, produksi paprika dalam empat tahun terakhir mengalami fluktuatif yang cukup signifikan, dimana pada tahun 2016 produksi paprika hanya mencapai 906,3 ton, sedangkan pada tahun 2017 produksi paprika mengalami kenaikan yang sangat tinggi mencapai 2.056 ton (Tabel 2). 
RISIKO RANTAI PASOK PAPRIKA PADA ANGGOTA

KELOMPOK TANI DEWA FAMILY, KABUPATEN BANDUNG BARAT

Mila Cahaya, Eliana Wulandari

Tabel 2. Luas Tanaman dan Produksi Paprika di Kabupaten Bandung Barat

\begin{tabular}{ccc}
\hline Tahun & Luas Tanaman $(\mathrm{Ha})$ & Produksi (Ton) \\
\hline 2014 & 324 & $1.246,3$ \\
2015 & 256 & $1.246,3$ \\
2016 & 475 & 906,3 \\
2017 & 473 & 2.056 \\
\hline
\end{tabular}

Sumber: BPS 2015-2018

Kecamatan Cisarua merupakan tinggi dengan mayoritas mata sentra produksi paprika di Kabupaten pencaharian utama penduduknya sebagai Bandung Barat. Salah satu desa di petani dan buruh tani tanaman sayuran. Kecamatan Cisarua yang banyak Komoditas utama yang dibudidayakan memproduksi paprika adalah Desa oleh penduduk Desa Pasirlangu adalah Pasirlangu, dengan produksi paprika pada tanaman paprika, tomat, bunga potong, tahun 2017 mencapai 1.561 ton (Tabel 3). labu siem dan sebagainya.

Wilayah ini merupakan daerah dataran

Tabel 3. Produksi Paprika Menurut Kecamatan di Kabupaten Bandung Barat

\begin{tabular}{|c|c|c|c|c|c|}
\hline \multirow{2}{*}{ No } & \multirow{2}{*}{ Kecamatan } & \multicolumn{4}{|c|}{ Produksi (ton) } \\
\hline & & 2014 & 2015 & 2016 & 2017 \\
\hline 1 & Batujajar & - & - & - & - \\
\hline 2 & Saguling & - & - & - & - \\
\hline 3 & Cisarua & 792,8 & 1036,5 & 466,5 & 1561 \\
\hline 5 & Cipatat & - & & - & - \\
\hline 6 & Cikalongwetan & - & & - & - \\
\hline 7 & Cipongkor & - & & - & - \\
\hline 8 & Cililin & - & & - & - \\
\hline 9 & Cihampelas & - & & - & - \\
\hline 10 & Gununghalu & - & & - & - \\
\hline 11 & Ngamprah & 49,1 & 17,8 & 88 & 115 \\
\hline 12 & Padalarang & - & & & - \\
\hline 13 & Parompong & - & & & - \\
\hline 14 & Rongga & - & & & - \\
\hline 15 & Sindangkerta & - & & & - \\
\hline 16 & Lembang & 319,9 & 192 & 343,8 & 360 \\
\hline
\end{tabular}


Kelompok Tani Dewa Family merupakan salah satu pelaku rantai pasok paprika di Desa Pasirlangu yang sudah menerapkan manajemen rantai pasok dimana terdapat struktur organisasi yang jelas dan pembagian kerja untuk keberlangsungan unit usahanya. Aktivitas rantai pasok memiliki peluang untuk timbulnya risiko seperti risiko dalam pengembangan produksi paprika (kuantitas, kualitas, dan kontinuitas), risiko pada kegiatan budidaya (hama dan penyakit, cuaca yang tidak menentu, dan tenaga kerja), risiko pemasaran (produktivitas menurun, permintaan tidak menentu, tidak ada kontrak antara mitra dan Kelompok Tani Dewa Family, dan fluktuasi harga), dan risiko keuangan (tidak ada manajemen keuangan dan perjanjian antara kelompok tani dengan petani perihal peminjaman modal). Pengelolaan risiko sangat diperlukan dalam penanganan risiko dan untuk meminimalisasi tingkat risiko dan dampak dari risiko (Hanafi, 2006). Oleh karena itu perlu dilakukan analisis dalam kegiatan rantai pasok paprika untuk mengidentifikasi risiko atau gangguan yang sedang dan akan timbul dalam kegiatan rantai pasok paprika, serta menentukan aksi mitigasi yang tepat terhadap risiko yang timbul tersebut.
Oleh karena itu, penelitian ini bertujuan untuk:

1. Mengidentifikasi rantai pasok paprika pada anggota Kelompok Tani Dewa Family.

2. Mengidentifikasi risiko yang terjadi pada rantai pasok paprika pada anggota Kelompok Tani Dewa Family.

3. Memilih alternatif tindakan seperti apa yang dapat dijadikan prioritas dalam mitigasi risiko pada rantai pasok paprika pada anggota Kelompok Tani Dewa Family.

\section{METODE PENELITIAN}

Penelitian ini dilakukan pada anggota Kelompok Tani Dewa Family, Desa Pasirlangu, Kecamatan Cisarua, Kabupaten Bandung Barat, dengan pertimbangan bahwa Kelompok Tani Dewa Family merupakan kelompok tani yang aktif melakukan kegiatan usahatani paprika. Kelompok Tani Dewa Family memiliki 8 anggota. Data dalam penelitian ini diperoleh melalui pengamatan langsung dan melakukan wawancara terhadap 8 orang anggota Kelompok Tani Dewa Family.

Analisis yang digunakan dalam penelitian ini adalah analisis deskriptif dan House of Risk (HOR). Analisis 
RISIKO RANTAI PASOK PAPRIKA PADA ANGGOTA

\section{KELOMPOK TANI DEWA FAMILY, KABUPATEN BANDUNG BARAT}

Mila Cahaya, Eliana Wulandari

deskriptif dalam penelitian ini digunakan untuk menjelaskan dan memetakan kegiatan anggota Kelompok Tani Dewa Family dalam proses rantai pasok paprika, mulai dari aliran barang, aliran uang, dan aliran informasi. Metode HOR merupakan modifikasi dari model Failure Mode and Effects Analysis (FMEA) untuk pengukuran risiko secara kuantifikasi dan model House of Quality (HOQ) untuk memprioritaskan mana agen risiko yang harus ditangani lebih dahulu dan untuk memilih tindakan yang paling efektif untuk mengurangi risiko potensial yang ditimbulkan oleh agen risiko (Geraldine, 2007; Pujawan, 2005). Pada penelitian ini, analisis risiko dengan menggunakan metode HOR dibagi menjadi dua fase, yaitu fase identifikasi risiko (risk identification) dan fase strategi proaktif. Output dari HOR fase 1 digunakan sebagai input pada fase 2. Dari fase pertama HOR, didapatkan nilai prioritas risiko dan level risiko dari masing-masing agen risiko yang telah teridentifikasi. Agen risiko yang terdapat pada level risiko tinggi menjadi input data pada tahap 1 dari HOR fase ke-2.

House of Risk fase 1 digunakan untuk menentukan agen risiko yang prioritas sebagai bentuk tindakan pencegahan. HOR 1 ini menggunakan tahapan sebagai berikut:

1. Identifikasi risiko yang mungkin terjadi pada setiap proses. Hal ini dapat dilakukan dengan memetakan setiap proses pada pelaku di Kelompok Tani Dewa Family dengan menggunakan SCOR (plan, source, make, deliver, dan return).

2. Identifikasi kejadian risiko (risk event) yang mungkin muncul pada setiap proses/kegiatan budidaya.

3. Identifikasi tingkat keparahan dampak (severity) pada setiap kejadian risiko (risk event). Tahap ini menggunakan skala 1-10, dimana skala 10 menunjukkan kejadian risiko yang sangat ekstrem. Kriteria severity disajikan pada Tabel 4.

4. Identifikasi agen/sumber risiko (risk agent) yang dapat menyebabkan terjadinya kejadian risiko.

5. Identifikasi agen/sumber risiko (risk agent) yang dapat menyebabkan terjadinya kejadian risiko. 
Tabel 4. Skala Severity

\begin{tabular}{|c|c|c|}
\hline Severity & Level & Kriteria \\
\hline No & 1 & Tidak ada efek \\
\hline Very slight & 2 & Petani tidak terganggu. Sangat sedikit efek pada produk atau sistem. \\
\hline Slight & 3 & Petani sedikit terganggu. Sedikit efek pada produk atau sistem. \\
\hline Minor & 4 & Petani mengalami gangguan kecil. Sedikit efek pada produk atau sistem. \\
\hline Moderate & 5 & $\begin{array}{l}\text { Petani mengalami beberapa ketidakpuasan. Efek sedang pada produk atau } \\
\text { sistem. }\end{array}$ \\
\hline Significant & 6 & $\begin{array}{l}\text { Petani mengalami ketidaknyamanan. Kondisi produk rusak tapi masih } \\
\text { beroperasi dengan aman. Gagal sebagian namun masih beroperasi. }\end{array}$ \\
\hline Major & 7 & $\begin{array}{l}\text { Petani tidak puas. Kondisi produk sangat terpengaruh tapi masih berfungsi dan } \\
\text { aman. Sistem terganggu. }\end{array}$ \\
\hline Extreme & 8 & Petani sangat tidak puas. \\
\hline Serious & 9 & Potensi efek berbahaya. \\
\hline Hazardous & 10 & Efek berbahaya. \\
\hline
\end{tabular}

Sumber: Stamatis (1995)

6. Identifikasi peluang kemunculan (occurrence) pada suatu agen/sumber risiko. Tahapan ini menggunakan skala 1-10 dimana nilai 1 memiliki arti tidak pernah terjadi sedangkan 10 memiliki arti hampir sudah pasti terjadi. Kriteria skala occurrence disajikan pada Tabel 5.

Tabel 5. Skala Occurrence

\begin{tabular}{lcl}
\multicolumn{1}{c}{ Occurrence } & Level & \multicolumn{1}{c}{ Kriteria } \\
\hline Almost never & 1 & Sejarah menunjukkan tidak pernah ada kegagalan \\
Remote & 2 & Kemungkinan kegagalan langka \\
Vert slight & 3 & Kemungkinan kegagalan sangat sedikit \\
Slight & 4 & Kemungkinan kegagalan beberapa \\
Low & 5 & Kemungkinan kegagalan sesekali \\
Medium & 6 & Kemungkinan kegagalan sedang \\
Moderately high & 7 & Kemungkinan kegagalan yang cukup tinggi \\
High & 8 & Kemungkinan kegagalan tinggi \\
Very high & 9 & Kemungkinan kegagalan sangat tinggi \\
Almost certain & 10 & Kegagalan pasti terjadi. Kegagalan pernah terjadi sebelumnya \\
\hline
\end{tabular}

Sumber: Stamatis (1995)

\section{Identifikasi korelasi (correlation)} antara kejadian risiko (risk event) dan agen/sumber risiko (risk agent) yang terjadi di Kelompok Tani Dewa Family. Apabila suatu agen/sumber risiko menyebabkan timbulnya suatu 


\section{RISIKO RANTAI PASOK PAPRIKA PADA ANGGOTA \\ KELOMPOK TANI DEWA FAMILY, KABUPATEN BANDUNG BARAT \\ Mila Cahaya, Eliana Wulandari}

kejadian risiko, maka dikatakan terdapat korelasi. Nilai korelasi ini juga memiliki bobot $(w)$, dimana semakin besar korelasi antara suatu agen/sumber risiko dengan kejadian risiko maka akan ditandai dengan skala nilai yang semakin besar. Skala korelasi agen/sumber risiko dan kejadian risiko dapat dilihat pada Tabel 6. Penilaian korelasi dalam penelitian ini dibatasi, dengan hanya dilakukan untuk risiko yang paling berdampak saja.

Tabel 6. Skala korelasi agen/sumber risiko dan kejadian risiko

\begin{tabular}{cl}
\hline Nilai Korelasi & \multicolumn{1}{c}{ Keterangan } \\
\hline 0 & Tidak terdapat hubungan antara kejadian risiko dengan penyebab risiko \\
1 & Hubungan kecil antara kejadian risiko dengan penyebab risiko \\
3 & Hubungan yang sedang antara kejadian risiko dengan penyebab risiko \\
9 & Hubungan yang tinggi antara kejadian risiko dengan penyebab risiko \\
\hline
\end{tabular}

Sumber: Pujawan dalam Faturohman (2015)

8. Hitung Agen Potential Risiko Agregat (ARP) yang merupakan hasil dari kemungkinan munculnya agen/sumber risiko dan akibat agregat dari terjadinya risiko yang disebabkan oleh sumber risiko. Urutkan sumber risiko berdasarkan nilai ARPj, mulai dari nilai terbesar sampai nilai terkecil. Aggregate Risk Potentials dari risk agent dapat dihitung dengan cara:

$$
\mathrm{ARP} J=0 / \sum_{i} \text { SiRij } \ldots(1)
$$

Keterangan:

ARPj $=$ Agen Potensial Risiko

Agregat

$\mathrm{Oj}=$ Peluang terjadinya risiko

$\mathrm{Si}=$ Dampak kejadian risiko
Rij $=$ Tingkat keterhubungan antara sumber risiko dengan kejadian risiko (korelasi)

Keseluruhan hasil dari langkah kerja di atas kemudian disajikan dalam satu tabel agar lebih mudah dibaca dan membantu mengefisienkan dalam proses perhitungan. Tampilan tabel kerja pada tahap House of Risk 1 (HOR1) yang telah dipaparkan di atas dapat dilihat pada Tabel 7. 
Tabel 7. Model HOR Fase 1

\begin{tabular}{|c|c|c|c|c|c|}
\hline \multirow{2}{*}{$\begin{array}{c}\text { Business } \\
\text { Processes }\end{array}$} & \multirow{2}{*}{$\begin{array}{c}\text { Risk } \\
\text { Event/ } E_{i}\end{array}$} & \multicolumn{3}{|c|}{ Risk Agents $/ A_{j}$} & \multirow{2}{*}{ Severity of risk event $/ S_{i}$} \\
\hline & & $A_{1}$ & $\mathrm{~A}_{2}$ & $\mathrm{~A}_{3}$ & \\
\hline Plan & $E_{1}$ & $\mathrm{R}_{11}$ & $\mathrm{R}_{12}$ & $\mathrm{R}_{23}$ & $\mathrm{~S}_{1}$ \\
\hline Source & $\mathrm{E}_{2}$ & $\mathrm{R}_{21}$ & $\mathrm{R}_{22}$ & & $\mathrm{~S}_{2}$ \\
\hline Make & $\mathrm{E}_{3}$ & $\mathrm{R}_{31}$ & & & $\mathrm{~S}_{3}$ \\
\hline Deliver & $\mathrm{E}_{4}$ & $\mathrm{R}_{41}$ & & & $\mathrm{~S}_{4}$ \\
\hline Return & $\mathrm{E}_{5}$ & & & & $\mathrm{~S}_{5}$ \\
\hline $\begin{array}{l}\text { Occurrence of } \\
\text { agent } j\end{array}$ & & $\mathrm{O}_{1}$ & $\mathrm{O}_{2}$ & $\mathrm{O}_{3}$ & \\
\hline $\begin{array}{l}\text { Aggregate risk } \\
\text { potential j }\end{array}$ & & $\mathrm{ARP}_{1}$ & $\mathrm{ARP}_{2}$ & $\mathrm{ARP}_{3}$ & \\
\hline $\begin{array}{l}\text { Priority rank of } \\
\text { agent } j\end{array}$ & & & & & \\
\hline
\end{tabular}

Sumber: Pujawan dan Geraldine (2009)

House of Risk fase 2 digunakan untuk menentukan penanganan mana yang harus diselesaikan terlebih dahulu. Perusahaan harus memilih aksi penanganan yang ideal, artinya tingkat kesulitannya rendah jika dilakukan namun akan efektif untuk mengurangi kemungkinan terjadinya agen atau sumber risiko. Tahap-tahap dalam HOR fase 2 ini adalah:

1. Memilih nomor sumber risiko dengan tingkat prioritas tinggi, dengan menggunakan diagram Pareto untuk menganalisis ARPj. Aplikasi hukum pareto pada risiko adalah $80 \%$ kerugian disebabkan oleh $20 \%$ risiko yang krusial. Apabila 20\% risiko krusial tersebut dapat diatasi maka perusahaan dapat menghindari $80 \%$ kerugian (Kountur, 2008). Kemudian dijadikan input pada House of Risk 2.

2. Mengidentifikasi aksi mitigasi yang dianggap berkorelasi dalam mencegah sumber risiko. Catatannya adalah sumber risiko dapat mengakibatkan lebih dari satu aksi dan satu aksi dapat mengurangi kemungkinan munculnya lebih dari satu agen atau sumber risiko.

3. Menentukan hubungan antara aksi pencegahan dengan setiap agen atau sumber risiko, Ejk bernilai antara $(0$, 1, 3, 9) dimana 0 berarti tidak ada korelasi, 1 berarti tingkat korelasi rendah, 3 berarti tingkat korelasi sedang, dan 9 berarti tingkat korelasi tinggi antara aksi (k) dan agen atau sumber risiko (j). Hubungan Ejk akan dianggap sebagai derajat keefektifan 
RISIKO RANTAI PASOK PAPRIKA PADA ANGGOTA

KELOMPOK TANI DEWA FAMILY, KABUPATEN BANDUNG BARAT

Mila Cahaya, Eliana Wulandari

dari aksi (k) dalam meminimalisir kemungkinan munculnya agen atau sumber risiko (j).

4. Menghitung total keefektian dari setiap aksi, menggunakan:

$$
\mathrm{TE}=\mathrm{Ejk} \times \mathrm{ARPk}
$$

5. Memberikan penilaian tingkat derajat kesulitan dalam setiap aksi, Dk, dan menempatkan nilai tepat di bawah nilai TE (Total Efektivitas). Derajat kesulitan dapat ditunjukkan dengan skala (seperti skala likert) yang mencerminkan dana dan sumber dana lain yang diperlukan dalam melakukan aksi tersebut. Menurut Pujawan dan Geraldine (2009), kesulitan dibagi menjadi 3 kategori yakni rendah dengan skor 3, sedang dengan skor 4, dan tinggi dengan skor 5, kategori derajat kesulitan dapat dilihat pada Tabel 8.

Tabel 8. Kategori Nilai Kesulitan dalam Melakukan Mitigasi

\begin{tabular}{ccl}
\hline No & $\begin{array}{c}\text { Kategori Nilai } \\
\text { Kesulitan }\end{array}$ & \multicolumn{1}{c}{ Makna Kategori Nilai Kesulitan } \\
\hline 1 & 3 & $\begin{array}{l}\text { (Low) dalam melaksanakan mitigasi, biaya yang dikeluarkan dirasa cukup } \\
\text { terjangkau dan tidak terlalu sulit dilaksanakan. } \\
(\text { Medium }) \text { dalam melaksanakan mitigasi, biaya yang dikeluarkan dirasa } \\
\text { cukup tinggi dan cukup sulit dilaksanakan. } \\
\text { (High) dalam melaksanakan mitigasi, biaya yang dikeluarkan dirasa tinggi } \\
\text { dan sulit dilaksanakan. }\end{array}$ \\
\hline
\end{tabular}

Sumber: Pujawan dan Geraldine (2009)

6. Menghitung rasio antara total keefektifan dengan kesulitan menggunakan rumus:

$$
\mathrm{ETD}_{\mathrm{k}}=\mathrm{TE}_{\mathrm{k}} / \mathrm{D}_{\mathrm{k}}
$$

Keterangan:

$\mathrm{ETDk}=$ Rasio antara total keefektifan dan kesulitan

TEk $=$ Total keefektifan

Dk = Tingkat Kesulitan
7. Beri urutan prioritas untuk setiap aksi (Rk) dimana urutan 1 merupakan urutan dengan nilai rasio total keefektifan dan kesulitan tertinggi (ETDk). 
Tabel 9. House of Risk 2

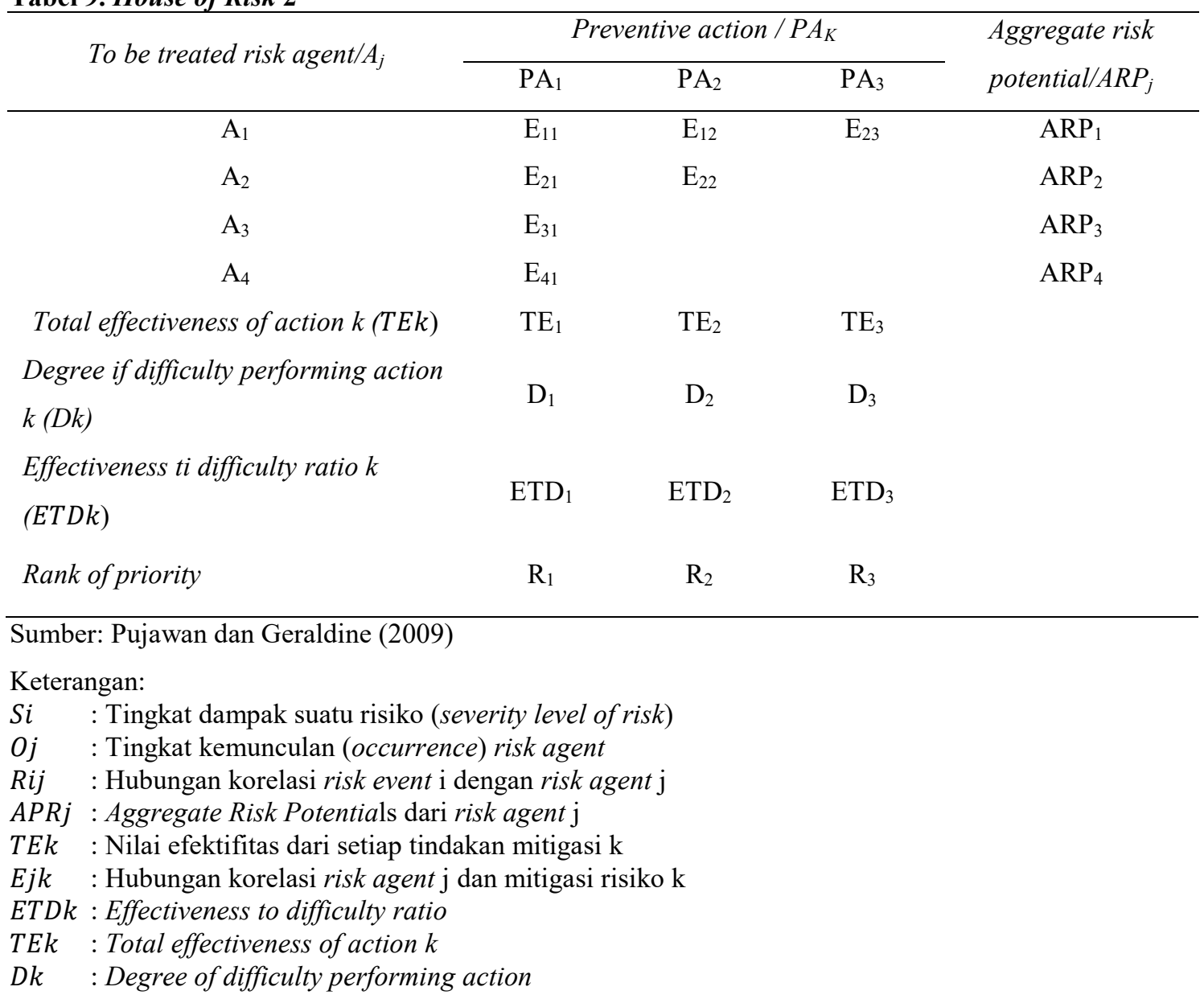

\section{HASIL DAN PEMBAHASAN}

Kelompok tani adalah kelembagaan di tingkat petani yang dibentuk untuk mengorganisir para petani dalam berusaha tani. Kelompok tani merupakan bagian integral pembangunan pertanian memiliki peran dan fungsi penting dalam menggerakkan pembangunan pertanian di perdesaan (Hermanto dan Swastika, 2011). Kelompok Tani Dewa Family merupakan kelompok tani pionir dalam pengembangan paprika hidroponik. Kelompok Tani ini didirikan pada tahun
2000 bergerak dalam bidang pemasok sayuran yang memiliki lahan budidaya sendiri. Kelompok Tani Dewa Family 2018 mempunyai 18 hektar lahan paprika di Desa Pasirlangu untuk memproduksi paprika hijau, merah, kuning, dan oranye.

Pada tahun 2017 produksi paprika di Kelompok Tani Dewa Family baru mampu menghasilkan 265 ton paprika yang menurun dari tahun-tahun sebelumnya (Tabel 10). Penurunan produksi disebabkan karena beberapa faktor seperti cuaca yang tidak menentu, 
RISIKO RANTAI PASOK PAPRIKA PADA ANGGOTA

\section{KELOMPOK TANI DEWA FAMILY, KABUPATEN BANDUNG BARAT}

Mila Cahaya, Eliana Wulandari

hama dan penyakit, permodalan, dan tenaga kerja. Jumlah produksi saat ini tidak dapat memenuhi seluruh permintaan, sehingga kelompok tani harus membeli paprika dari luar daerah seperti Garut dan Malang untuk memenuhi permintaan pasar.

Tabel 10. Data Produksi Paprika di Kelompok Tani Dewa Family tahun 2014-2017

\begin{tabular}{ccc}
\hline Tahun & Produksi (Ton) & Permintaan (Ton) \\
\hline 2014 & 358 & 400 \\
2015 & 326 & 400 \\
2016 & 287 & 500 \\
2017 & 265 & 500
\end{tabular}

Sumber: Kelompok Tani Dewa Family (2018)

Aktivitas Rantai Pasok Petani Paprika Anggota Kelompok Tani Dewa Family

1. Plan (perencanaan)

Aktivitas perencanaan yang dilakukan oleh petani meliputi perencanaan jadwal tanam, pengadaan, produksi, dan budidaya. Perencanaan pengadaan meliputi perencanaan pengadaan faktor produksi berupa sarana produksi tanaman (saprotan), tenaga kerja dan permodalan. Tenaga kerja adalah buruh tani yang melakukan kegiatan penanaman, pemeliharaan budidaya, dan panen. Sementara permodalan adalah sumber dana yang digunakan petani untuk melakukan kegiatan usahataninya.

Perencanaan pengadaan faktor produksi berupa benih dilakukan pada saat penanaman baru. Saprotan didapatkan dari toko saprotan Kelompok
Tani Dewa Family yaitu berupa benih, pupuk, obat-obatan, dan peralatan pertanian. Anggota kelompok tani mendapatkan akses pinjaman untuk mengambil saprotan dan dibayar ketika sudah masa panen dengan kesepakatan bahwa anggota kelompok tani harus menyalurkan paprikanya ke kelompok tani. Wulandari dkk (2017) menyebutkan bahwa petani dapat memperoleh pembiayaan dari kios pupuk dalam bentuk fleksibilitas pembayaran dengan kesepakatan bahwa seluruh atau sebagian hasil panen petani dijual kepada kios pupuk.

Perencanaan budidaya dilakukan meliputi jadwal tanam, persiapan lahan, penyemaian benih paprika, proses penanaman, pemeliharaan serta pemanenan yang dilakukan secara bertahap. Jadwal tanam mencakup waktu 
penanaman yang tepat untuk melakukan kegiatan penanaman mulai dari menyemai benih hingga pindah tanam pada media sekam. Kegiatan pemeliharaan paprika terdiri dari beberapa kegiatan yaitu penyiraman, pemupukan, pemangkasan, pemilihan cabang, pewiwilan, seleksi buah, serta pengendalian hama dan penyakit yang sering kali menyerang tanaman paprika. Pengobatan paprika dilakukan 1 minggu sekali. Sementara pemanenan paprika dilakukan setiap hari pada masa awal panen kemudian 2 sampai 3 hari sekali pada masa akhir panen, masa panen selama 4 bulan. Kegiatan pemeliharaan dan pemanenan dilakukan oleh petani dan buruh tani. Terdapat pembagian tugas antara buruh perempuan dan buruh laki-laki. Buruh laki-laki melakukan kegiatan penanaman, pemupukan, pengobatan dan pemanenan, sedangkan buruh perempuan melakukan kegiatan penyemaian benih dan pemanenan.

\section{Source (Pengadaan)}

Aktivitas pengadaan yang dilakukan oleh petani adalah pengadaan faktor produksi berupa saprotan, tenaga kerja, dan permodalan. Saprotan yang digunakan meliputi benih, pupuk, obatobatan, dan peralatan pertanian. Peralatan yang digunakan adalah arang sekam bakar, tray semai, hand sprayer, polibag, mulsa, benang kasur, dan keranjang.

Pengadaan tenaga kerja, buruh tani yang bekerja untuk penanaman, pemeliharaan dan pemanenan merupakan warga sekitar Desa Pasirlangu. Untuk pengadaan permodalan petani hanya mengandalkan modal sendiri dan pinjaman kepada keluarga, apabila ada kekurangan untuk saprotan petani anggota bisa meminjam terlebih dahulu ke Kelompok Tani Dewa Family.

3. Make (Produksi)

Proses produksi budidaya paprika yang dilakukan oleh petani meliputi kegiatan persiapan lahan, penyemaian benih paprika, proses penanaman, pemeliharaan, serta pemanenan yang dilakukan secara bertahap. Kegiatan pemeliharaan paprika terdiri dari beberapa kegiatan yaitu penyiraman, pemupukan, pemangkasan, pemilihan cabang, pewiwilan, seleksi buah, serta pengendalian hama dan penyakit.

a) Persiapan greenhouse

Petani paprika di Desa Pasirlangu dalam menjalankan kegiatan budidaya dilakukan dalam greenhouse. Adapun greenhouse yang digunakan oleh para petani terbuat dari bambu dan plastik UV sebagai atap dan dindingnya. Pada tahap persiapan greenhouse terdapat 
RISIKO RANTAI PASOK PAPRIKA PADA ANGGOTA

\section{KELOMPOK TANI DEWA FAMILY, KABUPATEN BANDUNG BARAT}

Mila Cahaya, Eliana Wulandari

beberapa kegiatan yang biasanya dilaksanakan oleh para petani yaitu pembuatan bedengan, sanitasi dan sterilisasi, serta perbaikan greenhouse seperti penggantian plastik UV yang mengalami kebocoran ataupun penggantian konstruksi bambu yang rusak atau sudah mulai rapuh.

b) Penyemaian benih

Penyemaian benih dilakukan pada saat greenhouse sedang dibersihkan dan didiamkan untuk proses sterilisasi. Penyemaian dilakukan untuk memperoleh bibit paprika yang nantinya dipindah tanamkan pada polibag, penyemaian membutuhkan waktu satu bulan hingga bibit siap tanam.

Benih yang akan disemai terlebih dahulu direndam air hangat sekitar satu jam, hal ini dimaksudkan untuk memperoleh pertumbuhan kecambah yang cepat dan seleksi benih saat akan dimasukkan atau disebar di tray. Kemudian satu per satu biji benih paprika dimasukkan ke dalam tray, satu lubang tray untuk satu benih dan didiamkan selama 10-15 hari.

Pemeliharaan benih dilakukan setiap hari untuk memastikan kondisi benih terjaga tidak terserang hama maupun penyakit dan pertumbuhan benih dapat berjalan dengan baik. Penanganan yang dilakukan pada saat benih tersebut berada pada tahap semai adalah penyiraman, pemberian nutrisi, penyemprotan insektisida untuk mencegah hama thrips yang sering kali menyarang tanaman paprika. Setelah berumur 30 hari, kemudian benih yang telah menjadi bibit dipindahkan ke dalam polibag semai yang telah diisi arang sekam.

c) Penanaman

Penanaman dilakukan menggunakan polibag dengan media tanam berupa arang sekam. Penggunaan arang sekam ini dipilih oleh petani karena dapat meningkatkan produktivitas dan hasil panen paprika lebih baik dibandingkan dengan media tanah, selain itu media arang sekam juga lebih mudah pengolahannya. Arang sekam memiliki karakteristik yang ringan, kasar sehingga sirkulasi udara tinggi, dan kemampuan menahan air tinggi sehingga mengabsorpsi sinar matahari dengan baik. Polibag yang digunakan berukuran $33 \times 35 \mathrm{~cm}$ dan pada setiap polibag diberi lubang untuk jalan keluar air sisa penyiraman. Pada setiap bedengan terdapat dua tanaman 
paprika yang ditanam sejajar dengan jarak sekitar $30 \mathrm{~cm}$.

Polibag yang telah berisi arang sekam terlebih dahulu diberi nutrisi dan didiamkan 1-2 hari kemudian bibit siap dipindah tanamkan. Penanaman yang dilakukan oleh petani biasanya pagi atau sore hari, untuk menjaga suhu di greenhouse agar tidak terlalu panas sehingga tanaman tidak menjadi layu dan tidak terlalu lembap.

d) Pemeliharaan

Faktor yang menentukan keberhasilan dalam melaksanakan budidaya paprika adalah buruh tani atau petani melaksanakan proses pemeliharaan. Korelasinya pun dianggap positif dimana ketika seorang petani melakukan pemeliharaan yang baik dan dilakukan secara maksimal maka diharapkan hasil produksi pun maksimal serta memiliki kualitas buah yang baik pula. Adapun kegiatan pemeliharaan yang dilaksanakan dalam melakukan budidaya paprika adalah penyiraman, dan pemupukan, pemilihan cabang, pewiwilan, seleksi buah, dan pengendalian hama dan penyakit.

e) Penyiraman dan pemupukan

Penyiraman dan pemberian nutrisi dilakukan setiap hari. Rata-rata penyiraman dilakukan dua kali sehari yaitu pagi dan sore hari dan ketika cuaca cukup panas penyiraman dilakukan tiga kali sehari. Sebaliknya jika cuaca sedang musim hujan penyiraman hanya dilakukan satu kali sehari. Pemberian nutrisi dilakukan secara bersamaan dengan penyiraman, pemberian nutrisi yaitu dua kali sehari. Namun ada juga petani yang memberikan nutrisi setiap hari.

Penyiraman yang dilakukan masih dilakukan secara manual. Penyiraman yang dilakukan dengan menggunakan sistem drip irrigation atau sistem irigasi tetes sehingga mempermudah pengontrolan jumlah pemberian dan menghemat biaya tenaga kerja. Namun sistem ini belum banyak diterapkan oleh para petani karena biaya yang cukup tinggi.

Berdasarkan Standar Operasional Prosedur (SOP) pemeliharaan paprika menurut Moekasan dkk (2008) fertigasi merupakan salah satu faktor yang menentukan keberhasilan budidaya paprika dimana volume fertigasi pun tergantung pada umur tanaman, volume fertigasi pada fase vegetatif $(1-<6 \quad$ MST $)$ rata-rata sebanyak $600 \mathrm{ml} /$ tanaman/hari. Pada fase berupa awal tumbuh buah (6-8 
RISIKO RANTAI PASOK PAPRIKA PADA ANGGOTA

\section{KELOMPOK TANI DEWA FAMILY, KABUPATEN BANDUNG BARAT}

Mila Cahaya, Eliana Wulandari

MST) sebanyak $900 \mathrm{ml} /$ tanaman/hari, sedangkan untuk fase pematangan buah hingga proses panen adalah sebanyak $1500 \mathrm{ml} /$ tanaman/hari. Tetapi keadaan aktual di lapangan berdasarkan hasil wawancara hampir semua petani memberikan jumlah yang sama untuk setiap fase. Hal ini tentu berpengaruh terhadap proses pertumbuhan paprika. Adapun jumlah nutrisi yang diberikan rata-rata adalah 0,3-1 liter larutan pekat yang sudah dicampur dengan air untuk pertanaman per harinya.

f) Pemilihan Cabang Utama

Pemilihan cabang utama biasanya dilakukan setelah usia tanaman menginjak 4 minggu dari setelah tanam. Setiap tanaman paprika biasanya akan memiliki 3 hingga 5 cabang. Sehingga perlu dilakukan pemilihan cabang utama yang akan dipelihara hingga menghasilkan buah.

g) Pembuangan Buah Pertama, Pewiwilan, dan Seleksi Buah

Pembuangan buah pertama dilakukan bersama dengan pemilihan cabang utama. Hal ini dilakukan agar nutrisi yang ada pada tanaman tidak habis oleh buah tersebut melainkan digunakan tanaman untuk memperkuat batang serta pertumbuhan tanaman dapat lebih cepat.

Pewiwilan merupakan kegiatan pemeliharaan tanaman paprika yang dilakukan rata-rata seminggu sekali yaitu membuang tunas air yang berada di batang tanaman. Selain itu pada saat tersebut dilakukan juga pemangkasan terhadap daun, mahkota bunga, yang menutupi atau mengganggu pertumbuhan buah. Pewiwilan serta pemangkasan bertujuan agar cahaya dan sirkulasi udara terhadap buah dapat berjalan optimal serta mengurangi risiko hama dan penyakit.

Seleksi buah dilakukan dengan cara membuang buah yang kiranya akan tumbuh kurang bagus sehingga pada saat panen buah tidak tumbuh maksimal. Seleksi buah juga dilakukan dalam penentuan warna untuk disiapkan agar dapat bagus ketika dipetik saat panen.

h) Pengendalian Hama dan Penyakit

Hama dan penyakit tanaman merupakan sesuatu yang dapat mengganggu proses budidaya serta pertumbuhan tanaman, dan dapat mempengaruhi kuantitas dan kualitas produksi yang dihasilkan. Berdasarkan hasil wawancara dengan para petani hampir seluruhnya mengatakan bahwa 
hama dan penyakit yang menyerang tanaman merupakan masalah utama dalam budidaya paprika. Serangan hama terus berulang pada setiap periodenya. Hama yang biasanya menyerang tanaman paprika yaitu hama thrips, tungau, dan ulat grayak. Kemudian untuk penyakit yang menyerang pada saat penanaman berlangsung adalah virus, tepung daun (powdery mildew), bercak daun, serta busuk akar (layu fusarium). Namun hama triphs merupakan hama yang paling banyak dan hampir menyerang setiap greenhouse yang dimiliki oleh petani. Hal tersebut terjadi karena tidak ada rotasi tanaman, pemberian dosis obat berlebih, serta tidak bersihnya lingkungan greenhouse dan tidak sesuai SOP budidaya.

Pemberian obat dilakukan dengan cara penyemprotan yang sering kali dilakukan sore hari karena suhu sudah mulai turun sehingga pestisida tidak akan menguap. Pemberian insektisida setiap satu minggu sekali bahkan ada yang satu minggu dua kali. Penyemprotan insektisida dimulai dari umur tanaman sekitar 1 minggu.

i) Pemanenan

Panen yang dilakukan pada tanaman paprika bertahap sesuai kondisi, buah sudah siap panen memiliki ciri-ciri warna buah yang mengkilap, mudah diambil dari tangkainya, serta daging buah telah mengeras dan tebal. Biasanya panen dilakukan setiap hari, panen dilakukan menggunakan gunting stek, dan untuk waktu pemanenan biasanya petani memanen paprika di pagi hari. Setelah panen biasanya dimasukkan ke dalam plastik bening berukuran besar dan setelah selesai dipanen kemudian paprika tersebut diambil oleh Kelompok Tani Dewa Family untuk dibawa ke gudang menggunakan mobil pick up.

2. Deliver (Pengiriman)

Para petani anggota Kelompok Tani Dewa Family dapat menyalurkan paprika langsung ke Kelompok Tani Dewa Family. Paprika yang telah dipanen lalu dikemas menggunakan plastik bening dengan berat $18 \mathrm{~kg}$ untuk paprika hijau, $20 \mathrm{~kg}$ untuk paprika merah, kuning, dan oranye. Hasil panen diambil oleh Kelompok Tani Dewa Family menggunakan mobil pick up.

Kebanyakan petani memilih untuk menyalurkan paprika ke kelompok tani dibandingkan menjualnya secara langsung ke distributor. Dengan 
RISIKO RANTAI PASOK PAPRIKA PADA ANGGOTA

\section{KELOMPOK TANI DEWA FAMILY, KABUPATEN BANDUNG BARAT}

Mila Cahaya, Eliana Wulandari

menyalurkan paprika ke kelompok tani tentunya akan memangkas biaya pengiriman yang harus dikeluarkan oleh petani.

3. Return (Pengembalian)

Pengembalian paprika tidak dilakukan karena Kelompok Tani menerima semua paprika yang dikirimkan oleh petani. Akan tetapi kelompok tani melakukan pemotongan harga pada produk paprika yang tidak sesuai standar. Dengan begitu, petani tidak memiliki risiko pengembalian barang dalam aktivitas ini.

\section{Analisis House of Risk (HOR) Tahap 1}

Setelah mengidentifikasi aktivitas di petani, dengan diskusi bersama petani, ditemukan beberapa peristiwa risiko yang terjadi pada setiap proses rantai pasok paprika di petani. Pada tingkat ini teridentifikasi 24 peristiwa risiko yang berpeluang muncul pada aktivitas rantai pasok paprika, yang disajikan pada Tabel 11.

Tidak semua peristiwa risiko yang telah teridentifikasi memiliki tingkat keparahan dampak yang tinggi. Untuk mengetahui keparahan dampak yang ditimbulkan oleh suatu peristiwa risiko maka dilakukan pemberian nilai/bobot. Pemberian nilai/bobot pada keparahan dampak (severity) dilakukan berdasarkan diskusi dengan petani paprika yang merupakan anggota Kelompok Tani Dewa Family.

Berdasarkan Tabel 11, peristiwa risiko yang memiliki tingkat keparahan dampak (severity) tertinggi di tingkat petani adalah terserang hama dan penyakit (E15). Petani dalam membudidayakan paprika cenderung tidak melakukan rotasi tanaman dengan alasan bahwa ketika rotasi dilakukan maka pasokan tidak dapat terpenuhi, hal ini pun berdampak terhadap hama dan penyakit yang menyerang tanaman. Hama hampir menyerang setiap periode tanam paprika adalah hama triphs sehingga membuat produksi petani banyak yang mengalami penurunan atau bahkan gagal panen. Penyakit yang sangat membahayakan bagi petani paprika adalah virus, apabila tanaman sudah terserang virus maka seluruh tanaman paprika harus ditebang sebelum waktu panen. Penanganan dalam melakukan budidaya paprika juga terlihat masih kurang baik dan tidak sesuai prosedur dimana petani memberikan dosis obat melebihi standar yang dianjurkan pada kemasan obat tersebut. Dalam jangka panjang akan menyebabkan hama menjadi resisten terhadap obat tersebut. Sehingga 


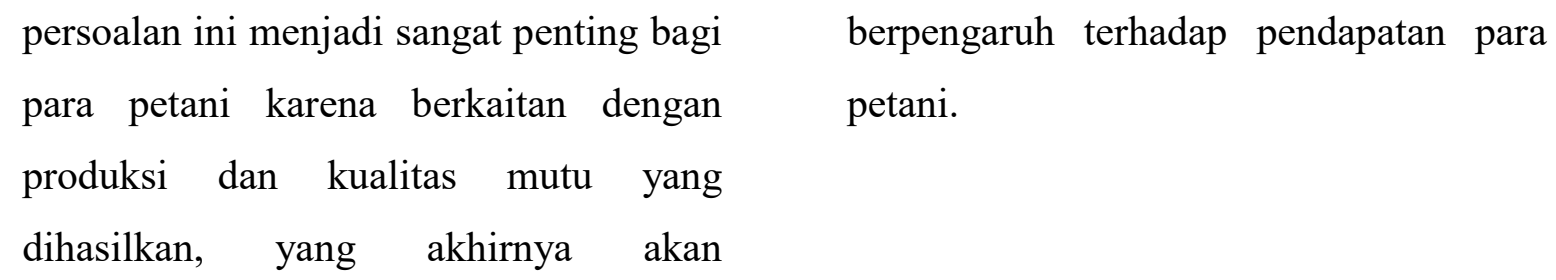

Tabel 11. Daftar Peristiwa Risiko dan Tingkat Keparahan Dampak pada Proses Rantai Pasok Paprika

\begin{tabular}{|c|c|c|c|c|}
\hline Proses Rantai Pasok & Sub-proses & Peristiwa Risiko (Risk Event) & Kode & $\begin{array}{c}\text { Keparahan } \\
\text { Dampak } \\
\text { (Severity) }\end{array}$ \\
\hline \multirow[t]{8}{*}{ Plan (Perencanaan) } & \multirow{4}{*}{$\begin{array}{l}\text { Perencanaan } \\
\text { penyediaan input } \\
\text { produksi } \\
\text { Perencanaan } \\
\text { produksi }\end{array}$} & $\begin{array}{l}\text { Kesalahan perencanaan pengadaan } \\
\text { input produksi }\end{array}$ & E1 & 6,5 \\
\hline & & $\begin{array}{l}\text { Salah dalam perencanaan jadwal } \\
\text { tanam }\end{array}$ & E2 & 6 \\
\hline & & $\begin{array}{l}\text { Target produksi tidak sesuai dengan } \\
\text { perencanaan awal }\end{array}$ & E3 & 8 \\
\hline & & Kurangnya modal produksi & $\mathrm{E} 4$ & 7 \\
\hline & \multirow[t]{2}{*}{$\begin{array}{l}\text { Perencanaan } \\
\text { permodalan }\end{array}$} & $\begin{array}{l}\text { Susahnya peminjaman modal dari } \\
\text { lembaga atau kelompok tani }\end{array}$ & E5 & 6 \\
\hline & & Tidak ada pencatatan keuangan & E6 & 6 \\
\hline & \multirow{2}{*}{$\begin{array}{l}\text { Perencanaan } \\
\text { pemasaran }\end{array}$} & Informasi pasar kurang & E7 & 7,5 \\
\hline & & Kondisi harga pasar berfluktuatif & E8 & 7 \\
\hline \multirow[t]{3}{*}{ Source (Pengadaan) } & \multirow[t]{2}{*}{$\begin{array}{l}\text { Pengadaan } \\
\text { saprotan }\end{array}$} & $\begin{array}{l}\text { Pengadaan saprotan oleh Kelompok } \\
\text { Tani Dewa Family terlambat }\end{array}$ & E9 & 5 \\
\hline & & Mahalnya biaya input & E10 & 8,5 \\
\hline & $\begin{array}{l}\text { Pengadaan } \\
\text { tenaga kerja }\end{array}$ & Tenaga kerja tidak memadai & E11 & 7 \\
\hline \multirow[t]{11}{*}{ Make (Produksi) } & \multirow{3}{*}{$\begin{array}{l}\text { Proses } \\
\text { penanaman } \\
\text { paprika }\end{array}$} & Kualitas jenis benih tidak seragam & E12 & 6,5 \\
\hline & & $\begin{array}{l}\text { Kurangnya pengetahuan petani } \\
\text { terhadap SOP budidaya paprika }\end{array}$ & E13 & 7 \\
\hline & & Cuaca dan Iklim tidak menentu & E14 & 8 \\
\hline & \multirow{4}{*}{$\begin{array}{l}\text { Proses } \\
\text { pemeliharaan }\end{array}$} & Terserang hama dan penyakit & E15 & 9 \\
\hline & & $\begin{array}{l}\text { Kesalahan dalam pemeliharaan } \\
\text { tanaman paprika }\end{array}$ & E16 & 7 \\
\hline & & $\begin{array}{l}\text { Alat pertanian yang digunakan } \\
\text { masih tradisional }\end{array}$ & E17 & 5,5 \\
\hline & & Penggunaan pestisida berlebihan & E18 & 8 \\
\hline & \multirow[t]{2}{*}{ Proses panen } & Produktivitas rendah & E19 & 8 \\
\hline & & Kualitas rendah & $\mathrm{E} 20$ & 8 \\
\hline & \multirow{2}{*}{$\begin{array}{l}\text { Proses pasca } \\
\text { panen }\end{array}$} & Ukuran paprika tidak seragam & E21 & 7 \\
\hline & & $\begin{array}{l}\text { Peranan kelompok tani kurang } \\
\text { dalam penjualan hasil usahatani }\end{array}$ & E22 & 5 \\
\hline Delivery (Distribusi) & $\begin{array}{l}\text { Pengiriman ke } \\
\text { kelompok tani }\end{array}$ & $\begin{array}{l}\text { Pembayaran dari Kelompok Tani } \\
\text { Dewa Family terlambat }\end{array}$ & E23 & 7 \\
\hline Return (Pengembalian) & $\begin{array}{l}\text { Pengembalian } \\
\text { produk }\end{array}$ & $\begin{array}{l}\text { Pemotongan harga akibat produk } \\
\text { rusak }\end{array}$ & E24 & 8,5 \\
\hline
\end{tabular}




\section{RISIKO RANTAI PASOK PAPRIKA PADA ANGGOTA \\ KELOMPOK TANI DEWA FAMILY, KABUPATEN BANDUNG BARAT \\ Mila Cahaya, Eliana Wulandari}

Setelah mengidentifikasi peristiwa risiko dan memberi penilaian pada keparahan dampak (severity), selanjutnya adalah mengidentifikasi agen risiko atau penyebab munculnya peristiwa risiko.
Identifikasi agen risiko dan pemberian nilai kemungkinan terjadi (occurance) oleh peneliti dilakukan berdasarkan diskusi bersama petani paprika.

Tabel 12. Daftar Agen Risiko dan Nilai Kemungkinan Kejadian (Occurance)

\begin{tabular}{clc}
\hline Kode & \multicolumn{1}{c}{ Sumber Risiko } & Rata-Rata \\
\hline A1 & Perencanaan budidaya kurang tepat & 8 \\
A2 & Biaya input produksi tinggi & 8 \\
A3 & Kesalahan memilih varietas paprika & 6 \\
A4 & Petani tidak teliti dalam pencatatan (kemampuan manajerial) & 7 \\
A5 & Iklim dan cuaca & 8 \\
A6 & Kurangnya modal & 8,5 \\
A7 & Tidak ada pelatihan dari penyuluh pertanian & 5,5 \\
A8 & Sumberdaya manusia tidak terlatih & 8 \\
A9 & Petani kurang mengetahui informasi pasar & 8 \\
A10 & Organisme pengganggu tanaman (Hama trips) & 9 \\
A11 & Dosis pupuk yang digunakan tidak tepat & 8 \\
A12 & Standardisasi paprika tinggi & 8,5 \\
\hline
\end{tabular}

Setelah melakukan identifikasi terhadap peristiwa risiko dan agen risiko di tingkat petani, serta melakukan penilaian terhadap severity dan occurance, data tersebut kemudian dimasukkan ke dalam tabel HOR tahap 1 untuk mengetahui nilai ARP (Aggregat Risk Potential) pada masing-masing risiko. Agen risiko dengan nilai ARP tertinggi merupakan agen risiko yang memiliki pengaruh atau dampak pada aktivitas rantai pasok paprika di tingkat petani dan menjadi prioritas untuk ditangani terlebih dahulu. Hasil perhitungan nilai ARP pada HOR tahap 1 menunjukkan "standardisasi paprika tinggi" (A12) merupakan agen risiko dengan nilai ARP terbesar.

Standardisasi paprika yang tinggi dalam kegiatan usaha tani merupakan hal krusial karena menentukan pendapatan dan keuntungan dalam usahatani. Jika paprika tidak sesuai standardisasi yang ditetapkan maka dilakukan pemotongan harga yang diterima oleh petani dan tidak sebanding dengan biaya produksi yang dikeluarkan, maka petani paprika akan mengalami kerugian dan menemui hambatan untuk membiayai kegiatan usaha tani. Beberapa faktor yang 
menyebabkan kualitas paprika tidak memenuhi standar diantaranya iklim dan cuaca yang tidak menentu, varietas benih, terserang hama dan penyakit, dan faktor sumberdaya manusia yang tidak kompeten dalam pemeliharaan

Penetapan standardisasi pada paprika merupakan kesepakatan diantara mitra dengan kelompok tani. Standardisasi yang ditetapkan ialah ukuran paprika seragam, warna paprika cerah mengkilat, buah dalam keadaan segar, tidak terkena hama penyakit, tidak terdapat bercak. Dengan demikian, pemasok harus memenuhi standardisasi yang telah ditetapkan tersebut. Sehingga petani harus mampu memenuhi standar tersebut, jika tidak memenuhi maka akan mendapatkan potongan harga.

Tidak semua agen risiko mendapat penanganan yang dikarenakan keterbatasan biaya, tenaga, dan waktu. Oleh karena itu agen risiko prioritas perlu dilakukan. Agen risiko prioritas ditentukan dengan menggunakan hukum pareto atau hukum 80:20 dengan mengaplikasikan hukum pareto pada risiko bahwa $80 \%$ kerugian disebabkan oleh hanya $20 \%$ risiko yang krusial (Kontur, 2008). Bila 20\% risiko krusial tersebut dapat ditangani, maka perusahaan dapat menghindari $80 \%$ kerugian. Berdasarkan perhitungan penentuan kategori agen risiko prioritas, terdapat 7 agen risiko prioritas yang perlu diberikan aksi mitigasi.

\section{Analisis House of Risk (HOR) Tahap 2} Tahapan kedua dalam analisis House of Risk (HOR) yaitu HOR tahap 2. Dalam HOR tahap 2, dipilih beberapa aksi mitigasi yang dianggap efektif untuk mengurangi dampak yang ditimbulkan oleh agen risiko. Langkah dalam HOR tahap 2 ini dimulai dengan merumuskan aksi mitigasi yang sesuai untuk setiap agen risiko prioritas. Selanjutnya adalah menentukan hubungan antara aksi mitigasi dengan agen risiko prioritas yang perlu diberi penanganan. Setelah itu menghitung nilai Total Effectiveness (TEk), Degree of Difficulty (Dk), dan menghitung rasio Effectiveness to Difficulty (ETDk) untuk menghitung rangking prioritas aksi mitigasi yang ada.

Berdasarkan agen risiko prioritas hasil perhitungan menggunakan tabel pareto maka ditentukan beberapa rencana strategi penanganan (aksi mitigasi) untuk agen prioritas tersebut. Untuk menemukan aksi mitigasi atau proactive action (PA) yang sesuai, dilakukan diskusi mendalam dengan petani paprika. Pada tabel 13 terdapat beberapa aksi 


\section{RISIKO RANTAI PASOK PAPRIKA PADA ANGGOTA \\ KELOMPOK TANI DEWA FAMILY, KABUPATEN BANDUNG BARAT \\ Mila Cahaya, Eliana Wulandari}

mitigasi yang direkomendasikan untuk

petani berdasarkan agen risiko prioritas.

Tabel 13. Daftar Agen Risiko dan Aksi Mitigasi

\begin{tabular}{|c|c|c|c|}
\hline Kode & Agen Risiko Prioritas & Kode & Aksi Mitigasi \\
\hline \multirow[t]{2}{*}{ A12 } & $\begin{array}{l}\text { Standardisasi paprika } \\
\text { tinggi }\end{array}$ & PA1 & $\begin{array}{l}\text { Penerapan SOP lapangan yang didiskusikan bersama } \\
\text { kelompok tani }\end{array}$ \\
\hline & & PA2 & Pemeliharaan dilakukan sesuai SOP budidaya paprika \\
\hline A4 & $\begin{array}{l}\text { Petani tidak teliti } \\
\text { dalam pencatatan } \\
\text { (kemampuan } \\
\text { manajerial) }\end{array}$ & PA3 & Melakukan pencatatan setiap input produksi dan keuangan \\
\hline A10 & $\begin{array}{l}\text { Organisme } \\
\text { pengganggu tanaman }\end{array}$ & PA4 & $\begin{array}{l}\text { Menjalin hubungan yang lebih intensif dengan Lembaga } \\
\text { penyuluhan pemerintah, PPTK, dan juga perguruan tinggi } \\
\text { untuk melakukan penelitian dan pengembangan terkait } \\
\text { pemecahan masalah pada teknik budidaya dan hama penyakit }\end{array}$ \\
\hline A9 & $\begin{array}{l}\text { Petani kurang } \\
\text { mengetahui informasi } \\
\text { pasar }\end{array}$ & PA5 & $\begin{array}{l}\text { Menjalin komunikasi secara kontinu dengan kelompok tani } \\
\text { mengenai harga di pasaran }\end{array}$ \\
\hline \multirow[t]{2}{*}{ A6 } & Kurangnya modal & PA6 & Pengadaan saprotan oleh kelompok tani bagi petani anggota \\
\hline & & PA7 & Melakukan kredit pinjaman ke bank \\
\hline A11 & $\begin{array}{l}\text { Dosis pupuk yang } \\
\text { digunakan tidak tepat }\end{array}$ & PA8 & $\begin{array}{l}\text { Selalu membaca petunjuk pengguna pestisida yang tertera } \\
\text { secara saksama sebelum menggunakannya }\end{array}$ \\
\hline A5 & Iklim dan cuaca & PA9 & $\begin{array}{l}\text { Penerapan teknologi adaptasi dan mitigasi perubahan iklim } \\
\text { (kalender tanam) }\end{array}$ \\
\hline
\end{tabular}

Berdasarkan perhitungan pada tabel HOR tahap 2, aksi mitigasi yang harus didahulukan penanganannya yaitu "pemeliharaan dilakukan sesuai SOP budidaya paprika" (PA2). Petani melakukan budidaya paprika dengan cara turun temurun, belum menerapkan SOP budidaya, sehingga sangat penting bagi petani untuk mengetahui bagaimana SOP yang baik dan benar yang dapat diperoleh melalui pelatihan dari penyuluh pertanian di lapangan. Jahi dan Leilani (2006) menyebutkan bahwa salah satu tugas pokok penyuluh yang dianggap penting yaitu mengembangkan swadaya dan swakarya petani.
Petani maupun kelompok tani telah melakukan penelitian dan pengembangan budidaya tanaman paprika dengan perguruan tinggi. Dengan menjalin hubungan yang lebih intensif dengan perguruan tinggi dan meningkatkan aktivitas penelitian dan pengembangan, maka sudah membuka peluang bagi para petani paprika untuk mengatasi berbagai permasalahan budidaya di lapangan dan meningkatkan kualitas paprika agar petani bisa menjual paprika dengan harga tinggi dan tidak menerima pemotongan harga pada setiap penjualan. 


\section{KESIMPULAN DAN SARAN}

Kegiatan rantai pasok paprika pada anggota Kelompok Tani Dewa Family meliputi perencanaan, pengadaan saprodi dan tenaga kerja, proses penanaman paprika, pemeliharaan, panen dan pasca panen, pengiriman ke kelompok tani dan pengembalian produk. Berdasarkan hasil identifikasi risiko, anggota Kelompok Tani Dewa Family menghadapi 24 peristiwa risiko dengan tingkat keparahan dampak tertinggi yaitu serangan hama dan penyakit. Aksi mitigasi yang harus didahulukan berdasarkan hasil analisis yaitu perlunya pemeliharaan yang dilakukan sesuai SOP budidaya paprika.

Rekomendasi penelitian ini adalah perlunya meningkatkan hubungan kerja sama dengan perguruan tinggi dalam kegiatan pengembangan dan penelitian terkait teknik budidaya tepat guna untuk permasalahan budidaya paprika. Bagi pemerintah juga perlu melakukan sosialisasi rutin mengenai SOP budidaya paprika, penanganan hama dan penyakit, dan melakukan pendataan petani paprika sehingga membantu petani yang masih melakukan budidaya belum sesuai SOP.

\section{UCAPAN TERIMA KASIH}

Penulis mengucapkan terima kasih kepada para anggota Kelompok Tani Dewa Family yang telah bersedia menjadi responden dalam penelitian ini.

\section{DAFTAR PUSTAKA}

Badan Pusat Statistika Kabupaten Bandung Barat. (2018). Kecamatan Cisarua Dalam Angka.2017. Diakses pada tanggal 4 Agustus 2018 melalui: https://bandungbaratkab.bps.go.id/.

Badan Pusat Statistika Kabupaten Bandung Barat. (2018). Kabupaten Bandung Barat dalam Angka 2017. Bandung Barat: BPS Kabupaten Bandung Barat.

Badan Pusat Statistik. (2014-2017). Produksi Tanaman Hortikultura (paprika). Tabel Dinamis. Diakses pada tanggal 4 agustus 2018 melalui website: https://www.bps.go.id/.

Badan Pusat Statistik dan Departemen Pertanian. (2018). Laporan Tanaman Sayuran dan BuahBuahan Semusim.

Badan Pusat Statistik Provinsi Jawa Barat. (2018). Jawa Barat Dalam Angka 2018. Diakses pada tanggal 15 Agustus 2018 melalui https://www.bps.go.id/.

Badan Pusat Statistik. (2018). Persentase tenaga kerja informal sektor pertanian. Diakses pada tanggal 18 Januari 2019 melalui https://www.bps.go.id/.

Direktorat Jendral Hortikultura. (2016). Statistik produksi hortikultura 2015. Direktorat Jendral Hortikultura. Kementrian Pertanian Indonesia, Jakarta. Enzazaden. Paprika. 
Hanafi, M. (2006). Manajemen Resiko. Unit Penerbit dan Percetakan Sekolah Tinggi Ilmu Manajamen YKPN. Yogyakarta.

Hermanto \& Swastika. (2011). Penguatan Kelompok Tani: Langkah Awal Peningkatan Kesejahteraan Petani. Analisis Kebijakan Pertanian, 9(4): 371-390.

Kountur, R. (2008). Mudah Memahami Manajemen Risiko Perusahaan. Penerbit PPM. Jakarta.

Moekasan, T.K., Prabaningrum, L. \& Gunadi, N. (2008). Budidaya Paprika di Dalam Rumah Kasa Berdasarkan Konsepsi Pengendalian Hama Terpadu (PHT). Balitsa. Lembang.

Pujawan, I. \& Geraldin, L.H. (2009). House of risk: a model for proactive supply chain risk management. Business Process
Management Journal, 15(6): 953967.

Savaringga, R. (2013). Strategi pengembangan usaha cabai paprika hidroponik di koperasi petani mitra Sukamaju kecamatan Cisarua kabupaten Bandung Barat. Skripsi. IPB, Bogor.

Widaningrum, Miskiyah, \& Christina Winarti. (2016). Aplikasi Bahan Penyalut Berbasis Pati Sagu dan Antimikroba Minyak Sereh Untuk Meningkatkan Umur Simpan Paprika. Jurnal Penelitian Pascapanen Pertanian, 13(1).

Wulandari, E., Meuwissen, M.P., Karmana, M.H., \& Lansink, A.G.O. (2017). Access to Finance from Different Finance Provider Types: Farmer Knowledge of the Requirements. PloS One, 12(9). e0179285. 